MAKÜ FEBED

ISSN Online: 1309-2243

http://dergipark.ulakbim.gov.tr/makufebed

Mehmet Akif Ersoy Üniversitesi Fen Bilimleri Enstitüsü Dergisi 7(1): 11-26 (2016)

The Journal of Graduate School of Natural and Applied Sciences of Mehmet Akif Ersoy Univer sity 7(1): 11-26 (2016)

Araştırma Makalesi / Research Paper

\title{
Çivril-Baklan (Denizli) Ovasında Yeraltısuyuna İklim Değişikliğinin Etkisi
}

\author{
Fatma AKSEVER*, Ayşe EROĞLU \\ Süleyman Demirel Üniversitesi Mühendislik Fakültesi, Isparta \\ Geliş Tarihi (Received): 07.12.2015, Kabul Tarihi (Accepted): 29.01.2016 \\ $\square$ Sorumlu Yazar (Corresponding author)*: fatmaaksever@sdu.edu.tr \\ (6) +902462111322 且 +902462370859
}

\section{öz}

Çivril-Baklan Ovası Ege Bölgesi'nin en büyük ovalarından biridir. Ovanın yıllık ortalama yağış miktarı 409.56 mm, gerçek buharlaşma miktarı ise $472.44 \mathrm{~mm}$ olarak belirlenmiştir. Buharlaşma miktarının yağış miktarından büyük olması beslenim-boşalım ilişkileri açısından yeraltısuyunun olumsuz etkilenebileceğini göstermektedir. Çivril-Baklan Ovası De Martonne metoduna göre "step-yarı nemli arası", Erinç metoduna göre "yarı nemli" ve Aydeniz iklim sınıflandırma metoduna göre de "yarı kurak" iklim tipine sahiptir. Yeraltısuyu seviye ölçümleri ile yağış ve sıcaklık arasındaki ilişkilerin tespiti için ölçüm sonuçları irdelenmiş̧ir. Genel olarak yağışlı dönemde yeraltısuyu seviyesinin yağıştan beslenim miktarı ile doğru orantılı olarak artığı görülmektedir. Araştırma sonuçlarına göre, bölgede yeraltısuyu seviye değişimini etkileyen en önemli iklimsel parametre yağış miktarındaki değişikliklerdir.

Anahtar Kelimeler: Yağış, sıcaklık, yeraltısuyu seviyesi, Çivril-Baklan Ovası

\section{Impact of Climate Change on Groundwater in Çivril-Baklan (Denizli) Plain}

\section{ABSTRACT}

Çivril-Baklan Plain is one of the great plains of Aegean Region. Annual average rainfall of the plain is $409.56 \mathrm{~mm}$ and real evapotranspiration is $472.44 \mathrm{~mm}$. In the study area, groundwater can be negatively affected due to the large of evaporation than precipitation taking into consideration recharge-discharge relations. Çivril-Baklan Plain has according to De Martonne method "between steppe and semi-humid", Erinç method "semi-moist" and Aydeniz method "semi-arid" climate types. In this study, groundwater level, precipitation and temperature data were investigated. Generally, groundwater level is increased directly proportional rainfall in rainy period. According to the results, precipitation is the most important climatic parameter affecting the groundwater level changes in the region.

Keywords: Precipitation, temperature, groundwater level, Çivril-Baklan Plain 


\section{Giriş}

Artan nüfus, kentleşme, endüstrileşme vb. unsurlar, günümüzde mevcut su kaynaklarına olan intiyacı giderek artırmaktadır. Buna bağı olarak son yıllarda oluşan iklim değişikliği nedeniyle sıcaklıkların artması ve yağışlarda meydana gelen düzensizlikler de su kaynaklarını olumsuz yönde etkilemektedir. Bu nedenle ülkemizde suyun verimli kullanılması konusunda acil önlemlerin alınması kaçınılmaz hale gelmektedir. Bu konuda mevcut su kaynaklarının kontrollü kullanımı, yönetimi ve sürdürülebilirliği ile birlikte sulara iklimin etkisi de detaylı olarak incelenmelidir. Bu nedenle ovalarda yapılacak hidrolojik, hidrojeolojik ve klimatolojik çalışmalar ön plana çıkmaktadır. Çalışma alanı olarak seçilen Çivril-Baklan ovasında; yeraltısuyu potansiyeli ve sürdürülebilirliğine yönelik herhangi bir çalışma mevcut değildir.

Çivril-Baklan ovasını içine alan çalışma alanı, doğusunda yeralan Işıklı Gölü'ne kadar olan yayılımı ile yarı kapalı bir havza özelliği göstermektedir (Şekil 1). Bu bölge hem ovada bulundurduğu yeraltısuyu açısından hem de Işıklı Gölü'nü besleyen su kaynakları açısından oldukça zengin bir su potansiyeline sahiptir. Ayrıca, bölge günümüz sıcaklık artışlarının yoğun yaşandığı ve küresel ısınmaya maruz kalan bölgeler arasında yeralmaktadır. Bu doğrultuda artan iklim değişikliğinin bölgedeki mevcut su kaynaklarına etkisinin tespiti büyük önem taşımaktadır. Çalışmada Çivril-Baklan ovasında sıcaklık, yağış ve buharlaşma miktarlarındaki değişimlerin yeraltısuyuna etkisi araştırılmıştır.

\section{MATERYAL VE METOT}

Çivril-Baklan Ovasına ait 1/25 000 ölçekli jeoloji haritası ve tektono-stratigrafik sütun kesiti hazırlanmıştır. Çalışma alanında bulunan litolojik birimler akifer olabilme özelliklerine göre sınıflandırılmış, ayırtlanmış ve bölgeye ait 1/25 000 ölçekli hidrojeoloji haritası hazırlanmıştır. Havzaya ait ortalama yıllık yağışın hesaplanabilmesi için Eş Yağış Eğrileri (İzohyet) yöntemi kullanılmıştır.Arazide seviye ölçümü yapılan sondaj kuyularının koordinatlarını belirlemek için Magellan Triton 500 marka GPS kullanılmıştır. Ovayı temsil eden sondaj kuyuları seçilerek statik seviye ölçümleri yapılmış ve yeraltısuyuseviye haritası hazırlanmıştır.Buharlaşma miktarının belirlenmesinde Thornthwaite yöntemi (Thornthwaite ve Mather, 1957) kullanılmış ve havzanın deneştirmeli su bütçesi hazırlanmıştır. Çalışma alanına ait klimatolojik parametreler Orman ve Su İşleri Bakanlığı Devlet Meteoroloji Müdürlüğü'nden temin edilmiş ve elde edilen veriler değerlendirilerek bölgenin iklim sınıflandırması yapılmıştır. Havzanın iklim tipini belirleyebilmek için De Marton- ne, Erinç ve Aydeniz İklim sınıflandırma metotları kullanılmıştır.

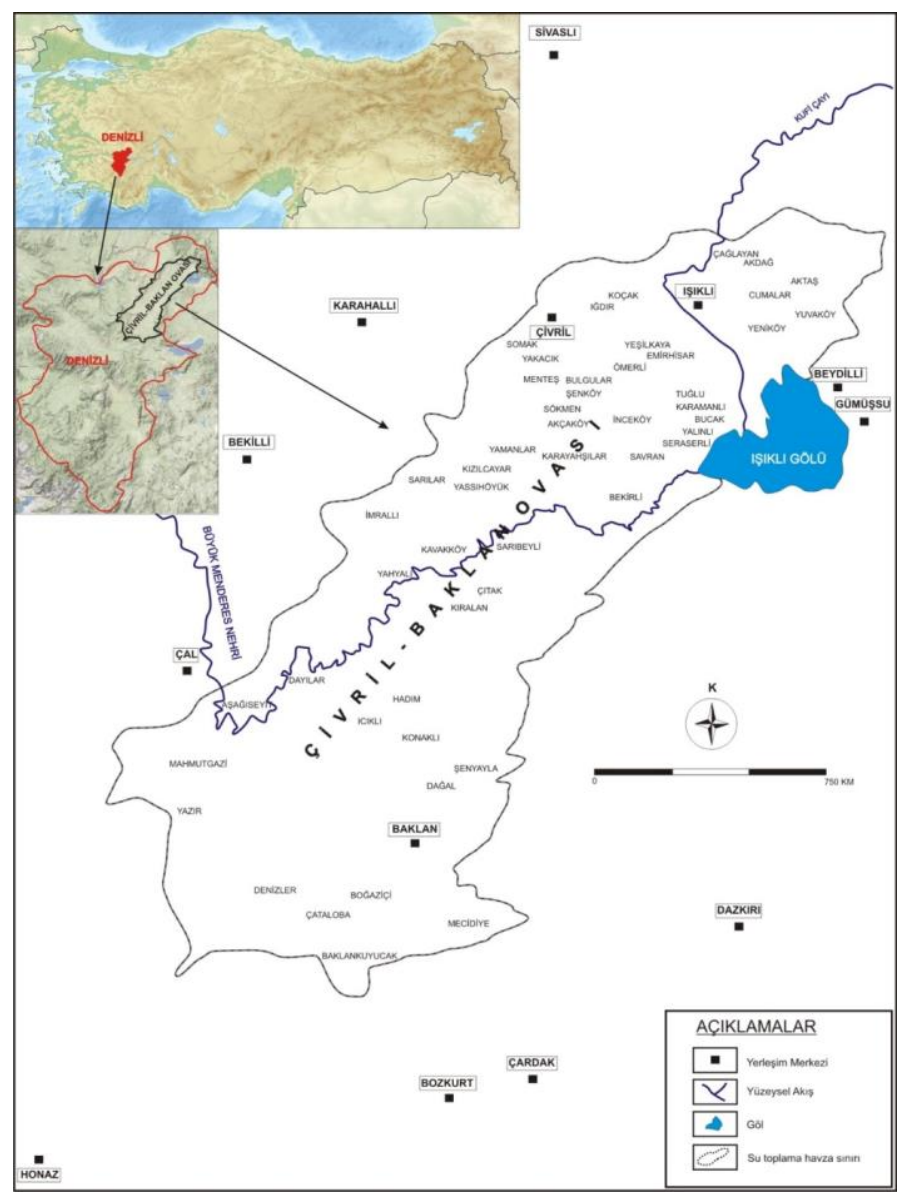

Şekil 1. İnceleme alanı yer bulduru haritası

\section{BULGULAR VE TARTIŞMA}

\section{Çalışma Alanı}

Çivril-Baklan Ovası ortalama 850m yüksekliği, 92.000 ha genişliği ile bölgenin en yüksek ve en geniş ovasıdır. Ovada yeraltısuyunun emniyetli rezerv durumu $30 \mathrm{hm}^{3} / \mathrm{yıl}$ olarak hesaplanmıştır (Özsoy, 2011). Çivril-Baklan Ovası kuzeyden güneye doğru uzanan geniş yayılımlı çöküntü alanı ile Çivril-Baklan grabenini oluşturmaktadır.Ege Bölgesi'nin en önemli akarsuyu olan Büyük Menderes nehri ovayı baştanbaşa sulayarak geçmektedir. Nehrin üzerinde sulama amaçlı kullanılan Işıklı baraj gölü yeralmaktadır. Ovanın diğer önemli yüzeysel akışı ise Kufi çayıdır. Kufi çayı ile Işıklı Gölü'ne açılan Çivril-Baklan Ovası yarı kapalı havza niteliğindedir (Şekil 1).

\section{Jeoloji}

Çalışma alanının tabanında Paleozoyik yaşı metamorfik kayaçlardan oluşan Menderes Masifi bulunmaktadır. 
Menderes masifi, mermer, granat şist, biyotit şist, kuvarsit, çörtlü mermer, çörtlü kristalize kireçtaşı, serizit ve klorit şistlerden oluşmaktadır. Metamorfik temelin üzerini ise fliş karakterindeki Oligosen yaşlı Bayıralan formasyonu uyumsuz şekilde örtmektedir. Bayıralan formasyonu konglomera, marn, linyit, kiltaşı, killi kireçtaşı ve kumtaşı ardalanmasından oluşan bir flişdir. Killi kireçtaşı, kireçtaşı, kiltaşı ve silttaşından oluşan Miyosen yaşlı Ulubey formasyonu ise Bayıralan formasyonu üzerinde uyumsuz olarak gelmektedir. Pliyosen-Miyosen yaşlı Çağlayan formasyonu, kiltaşı, marn, konglomera, kumtaşı, silttaşı ve çamurtaşından oluşmaktadır. Pliyosen yaşlı Killik formasyonu ise killi kireçtaşı, marn, kumtaşı, kiltaşı, konglomera, silttaşı ve çamurtaşından oluşmaktadır. Killik ve Çağlayan formasyonları birbiri ile tedrici geçişli olup Ulubey formasyonunu uyumsuz olarak örtmektedir. Güncel çökellerden oluşan Kuvaterner yaşlı Alüvyon ise tüm birimleri uyumsuz olarak üzerlemektedir (Konak vd., 1986; Sözbilir, 1997; Sonay, 2011) (Şekil 2).

\section{Hidrojeoloji}

Çivril-Baklan ova alanını oluşturan Kuvaterner yaşlı alüvyon yeraltısuyu bulundurma kapasitesi açısından oldukça zengin bir yapıya sahip olup "Taneli akifer" olarak nitelendirilmiştir. Killik formasyonu marn, kumtaşı ve killi kireçtaşı ardalanmasından oluşmaktadır.
Formasyonun içerdiği kumtaşı bantları ve kireçtaşı seviyeleri yeraltısuyu bulundurma kapasitesine sahiptir. Ancak kalın tabakalı marn ve kil seviyeleri yeraltısuyu içermez ve bu nedenle Killik formasyonu"Akitard ortam-1" olarak nitelendirilmiş.Çağlayan formasyonu konglomera, marn, kumtaşı, kiltaşı, silttaşı ve çamurtaşı ardalanmasından oluşmaktadır. Konglomera ve kumtaşı bantları kalınlıkları ve yayılımları oranında yeraltısuyu bulundurabilecek litolojilerdir. Ancak, formasyon içerisindeki marn, kiltaşı, silttaşı ve çamurtaşı tabakaları yeraltısuyu taşımamaktadır. Bu nedelne, Çağlayan formasyonu "Akitard ortam-2" olarak ayırtlanmıştır. Kireçtaşı, killi kireçtaşı ve silttaşı ardalanmasından oluşan Ulubey formasyonu içerisindeki kireçtaşları, karstik özelliğe sahip olduğu için erime boşlukları ve süreksizliklerinde yeraltısuyu bulundururlar. Ancak kil bantları ve silttaşı tabakaları geçirimsizdir. Bu nedenle formasyon "Akitard ortam-3" olarak sınıflandırılmıştır. Kumtaşı, kiltaşı, konglomera, marn ve killi kireçtaşı ardalanmasından oluşan Bayıralan formasyonu da akitard özelliğe sahiptir. Birim "Akitard ortam-4" olarak isimlendirilmiştir. Menderes masifi metamorfik ve tektonik süreçleri geçirmiş birbirleri ile geçişli litolojilerden oluşmaktadır. Birimin içeriğini kuvarsitik kumtaşı, fillit, kuvars-klorit-serisit şist, kuvars-feldispat-klorit şist, feldispat-kuvars serisit şist ve kuvars serisit şistler oluşturmaktadır. Metamorfik özelliğe sahip olan formasyon hidrojeolojik olarak geçirimsiz özelliğe sahip olup "Akifüj" olarak adlandırılmıştır (Şekil 3).

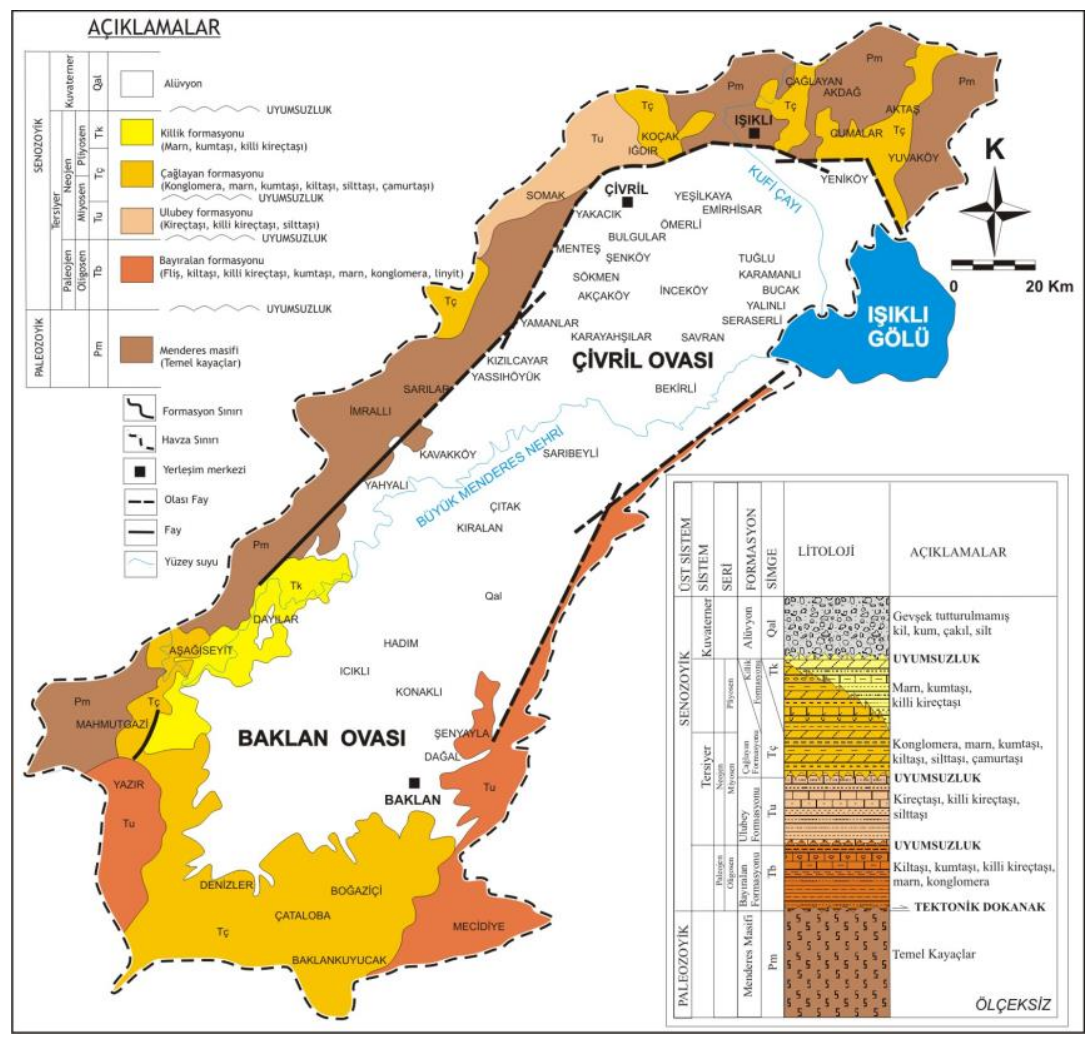

Şekil 2. İnceleme alanının jeoloji haritası (Sonay, 2011'den revize edilmiştir) 


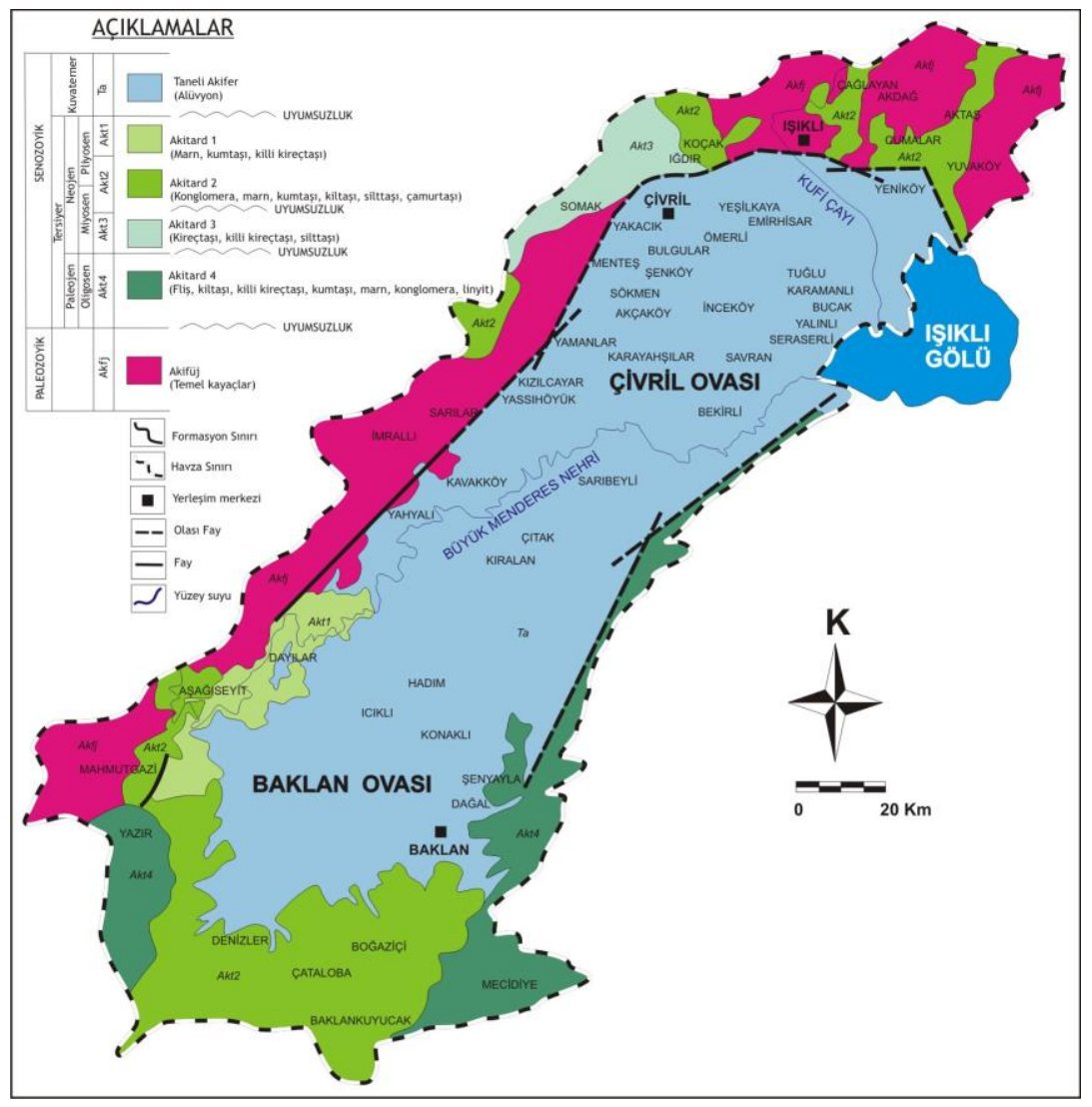

Şekil 3. İnceleme alanı hidrojeoloji haritası

\section{Hidroloji}

\section{İklim}

Çivril ve Baklan Ovası Ege Bölgesi'nde görülen Akdeniz iklimi ile İç Anadolu'da görülen Karasal iklim arasında geçiş tipi bir iklime sahiptir. Buna göre yazlar sıcak ve kurak, kışlar soğuk ve yağışlı geçmektedir. Meteoroloji Genel Müdürlüğü resmi istatistiklerine göre bölgedeki uzun yıllara (1974-2015) göre değişen sıcaklıklara bakıldığında en düşük sıcaklık Ocak ayında $22.6^{\circ} \mathrm{C}$, en yükseksıcaklık Ağustos ayında $44.4{ }^{\circ} \mathrm{C}$ 'dir. ÇivrilBaklan Ovası SPI (Standardized Precipitation Index) Standart Yağış İndeksi Metoduna göre "normal ve hafiforta nemli" sınıfında yeralmaktadır(Şekil 4). ÇivrilBaklan ovasının kuraklık yüzdesi ise PNI (Percent of Normal Index) Normalin Yüzdesi Metoduna göre "normal ve üzeri” olarak değerlendirilmiştir (Şekil 5) (MGM, 2015).

\section{Sıcaklık}

Çivril ilçesinde Orman ve Su işleri Bakanlığı Meteoroloji Genel Müdürlüğü tarafından iki adet meteoroloji istasyonu kurulmuştur. İlk istasyonda (no:5986) 1968-1992 yılında yıllık sıcaklık değerleri ölçülmüş ve kaydedilmiştir. Diğer istasyonda (no:17825) ise 2007-2015 tarihleri arasında sıcaklık ölçümleri kaydedilmiştir. 2015 yılında Çivril ilçesinde yıllık ortalama sıcaklık $12,3^{\circ} \mathrm{C}$ 'dir. Baklan ilçesinde ise tek bir istasyonda (no:6669) sadece 2 yıl süresinde (1988-1989) sıcaklık ölçümü yapılabilmiştir (Tablo 1). Çivril ilçesinde en yüksek sıcaklık Ağustos 2015 tarihinde $26.0^{\circ} \mathrm{C}$, en düşük sıcaklık ise Ocak $2015^{\prime}$ de $3.1^{\circ} \mathrm{C}$ olarak ölçülmüştür. Çivril'de 1969-1991 yılları arasında bölgenin sıcaklık miktarında kararlılık gözlenirken (Şekil 6), 2007-2015 yılları arasında ise sürekli artış (Şekil 7) gözlenmektedir. Bu durumun küresel ısınmaya bağlı olarak artış gösterdiği düşünülmektedir. 


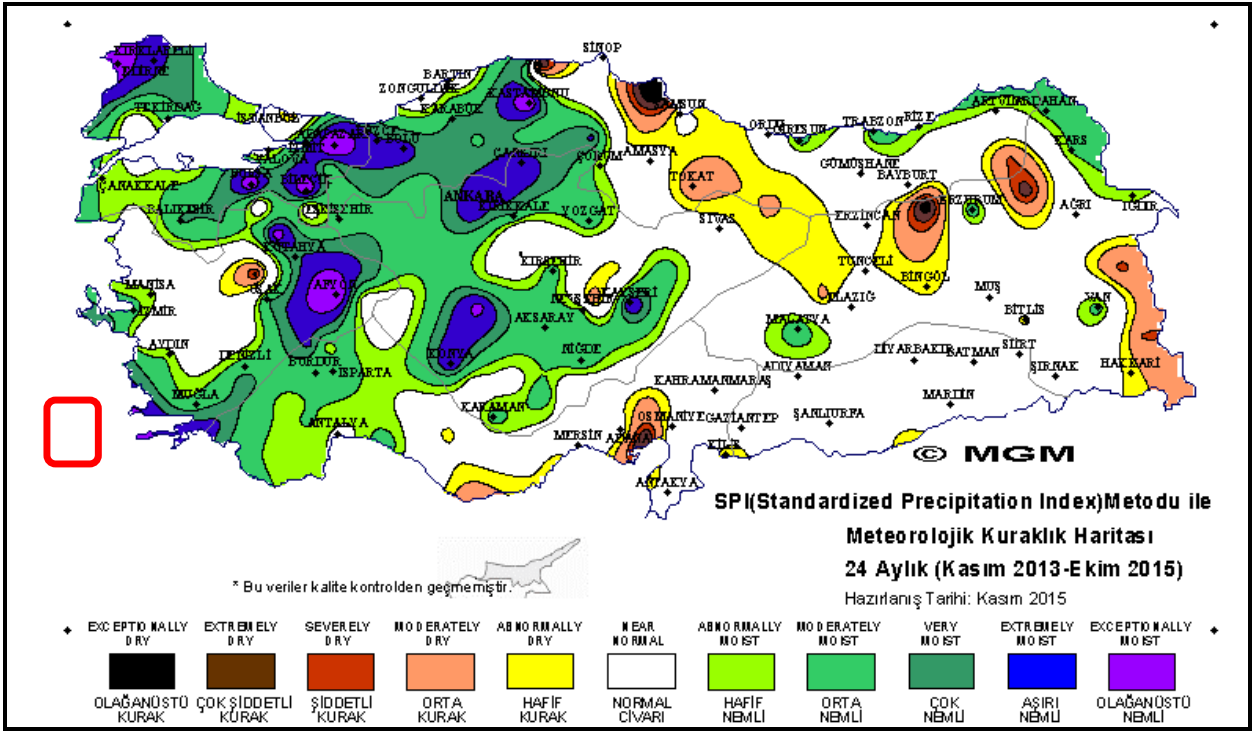

Şekil 4. Türkiye'nin SPI Metodu ile meteorolojik kuraklık haritası (MGM, 2015)

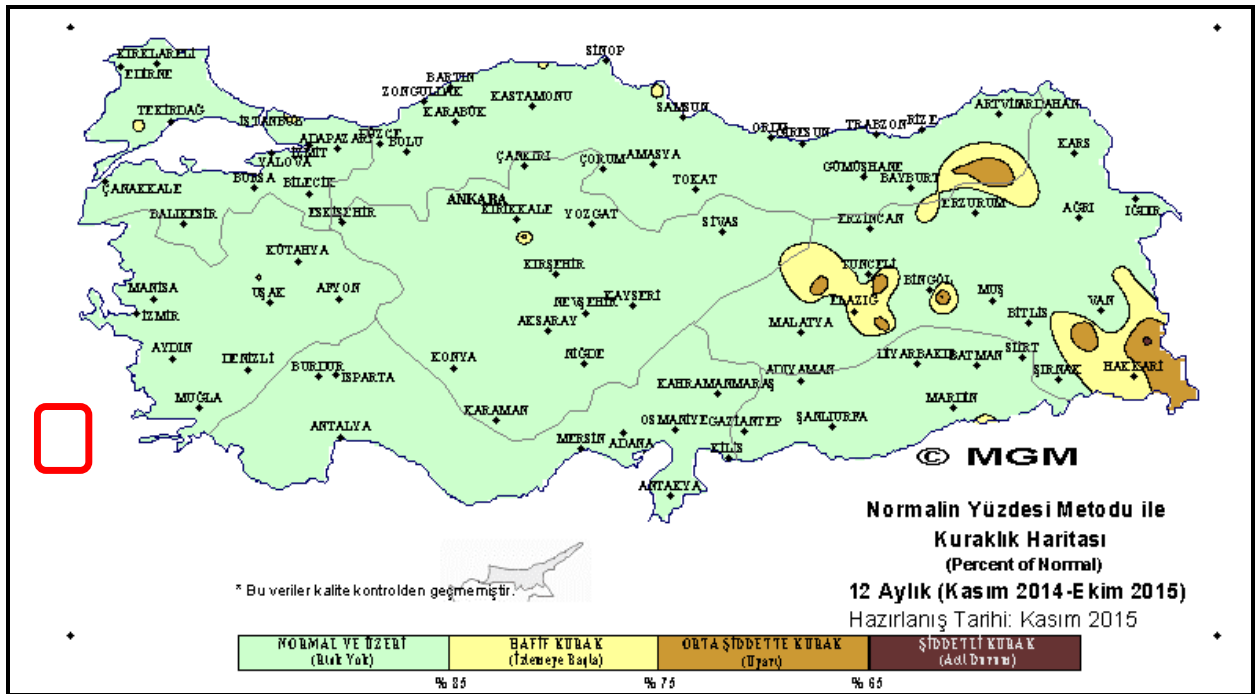

Şekil 5. Türkiye'nin PNI Metodu ile meteorolojik kuraklık haritası (MGM, 2015)

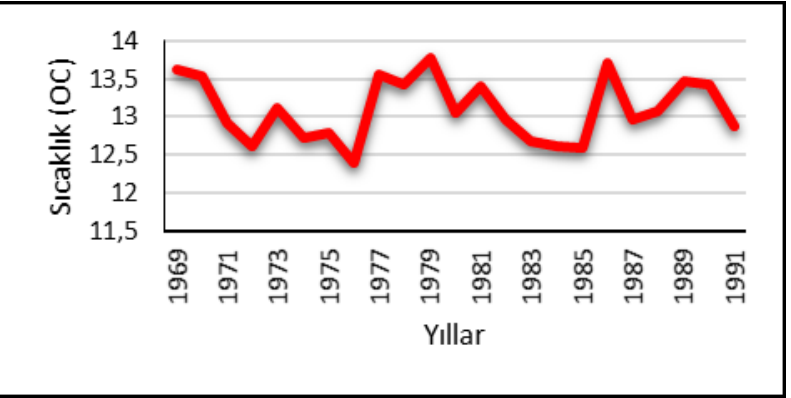

Şekil 6. Çivril'e ait sıcaklık değişimi (1969-1991)

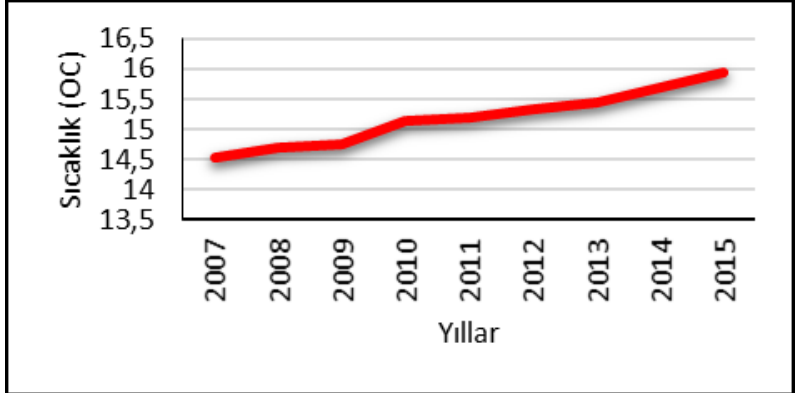

Şekil 7. Çivril'e ait sıcaklık değişimi (2007-2015) 
Tablo 1. İnceleme alanına ait yıllık ortalama sıcaklık değerleri (DMi, 2015)

\begin{tabular}{|c|c|c|c|c|c|c|c|c|}
\hline \multicolumn{6}{|c|}{ ÇIVRIL } & \multicolumn{3}{|c|}{ BAKLAN } \\
\hline $\begin{array}{c}\text { İstasyon } \\
\text { No }\end{array}$ & YII & $\begin{array}{l}\text { Ortalama } \\
\text { Sıcaklık } \\
\left({ }^{\circ} \mathrm{C}\right)\end{array}$ & $\begin{array}{c}\text { İstasyon } \\
\text { No }\end{array}$ & YII & $\begin{array}{c}\text { Ortalama } \\
\text { Sıcaklık } \\
\left({ }^{\circ} \mathrm{C}\right)\end{array}$ & $\begin{array}{c}\text { İstasyon } \\
\text { No }\end{array}$ & YII & $\begin{array}{c}\text { Ortalama } \\
\text { Sıcaklık } \\
\left({ }^{\circ} \mathrm{C}\right)\end{array}$ \\
\hline 5986 & 1969 & 14.4 & 17825 & 2007 & 14.6 & 6669 & 1988 & 13,0 \\
\hline 5986 & 1970 & 13.6 & 17825 & 2008 & 14.8 & 6669 & 1989 & 20.3 \\
\hline 5986 & 1971 & 13.0 & 17825 & 2009 & 14.9 & & & \\
\hline 5986 & 1972 & 12.7 & 17825 & 2010 & 15.1 & & & \\
\hline 5986 & 1973 & 13.2 & 17825 & 2011 & 15.4 & & & \\
\hline 5986 & 1974 & 12.8 & 17825 & 2012 & 15.6 & & & \\
\hline 5986 & 1975 & 12.9 & 17825 & 2013 & 15.7 & & & \\
\hline 5986 & 1976 & 12.4 & 17825 & 2014 & 15.8 & & & \\
\hline 5986 & 1977 & 13.6 & 17825 & 2015 & 15.9 & & & \\
\hline 5986 & 1978 & 13.5 & & & & & & \\
\hline 5986 & 1979 & 13.8 & & & & & & \\
\hline 5986 & 1980 & 13.1 & & & & & & \\
\hline 5986 & 1981 & 13.5 & & & & & & \\
\hline 5986 & 1982 & 13.0 & & & & & & \\
\hline 5986 & 1983 & 12.7 & & & & & & \\
\hline 5986 & 1984 & 5.8 & & & & & & \\
\hline 5986 & 1985 & 12.0 & & & & & & \\
\hline 5986 & 1986 & 13.8 & & & & & & \\
\hline 5986 & 1987 & 13.0 & & & & & & \\
\hline 5986 & 1988 & 13.1 & & & & & & \\
\hline 5986 & 1989 & 13.5 & & & & & & \\
\hline 5986 & 1990 & 13.5 & & & & & & \\
\hline 5986 & 1991 & 12.9 & & & & & & \\
\hline 5986 & 1992 & 13.0 & & & & & & \\
\hline
\end{tabular}

\section{Yağış}

Genel olarak yeraltısularının ve yüzeysularının en önemli beslenim elemanı yağıştır. Çivril-Baklan Ovası için ortalama yağış miktarının belirlenmesi amacıyla havza sınırları içerisinde ve civarında yeralan Devlet Meteoroloji istasyonlarında (DMi) ölçülen yıllık ortalama yağış verileri kullanılmıştır. İnceleme alanı ve yakın çevresinde Sandıklı, Hocalar, Gümüşsu, Kızı̈ören, Sivaslı, Karahallı, Bekilli, Çal, Pamukkale, Honaz, Çardak, Dazkırı, Dinar, Çivril ve Baklan yerleşim merkezlerinde bulunan gözlem istasyonları bulunmaktadır. Bu istasyonlardan elde edilen veriler ile ortalama yağış miktarı Eş Yağış Eğrileri (İzohyet) yöntemine göre hesaplanmıştır.Havzanın ortalama yıllık yağış miktarı ise 409.56 mm'dir (Şekil 8).

\section{Buharlaşma}

Genel olarak yeraltısuyu ve yüzeysularının en önemli boşalım elemanı buharlaşma-terleme miktarıdır. Doğrudan ölçümü kolay olmayan bu parametrenin belirlenmesi amacıyla farklı ampirik formüller üretilmiştir. Bunlardan en yaygın olarak kullanılanları Thornthwaite (Thornthwaite ve Mather1957) eşitliğidir. Bu yöntem ile havzaya ait sıcaklık ve yağış verileri ile havzanın potansiyel (Etp) ve gerçek (Etr) buharlaşma değerleri hesaplanmaktadır. Havzanın deneştirmeli su bilançosunda toplam ortalama yıllık yağış miktarı $499 \mathrm{~mm}$, potansiyel buharlaşma (Etp) değeri $1053.97 \mathrm{~mm}$ ve gerçek buharlaşma (Etr) değeri ise $472.44 \mathrm{~mm}$ olarak bulunmuştur (Tablo 2). Ayrıca, bu verilerden yararlanılarak yağış ve potansiyel buharlaşma grafiği hazırlanmıştır (Şekil 9). Grafikte, Ocak ayından Nisan ayının sonuna kadar yağışın $(P)$ potansiyel buharlaşmadan (Etp) fazla olduğu görülmektedir. Bu dönemlerde Etp, Etr'ye eşittir ve bu dönem için su fazlası $82.41 \mathrm{~mm}$ olarak hesaplanmıştır. $100 \mathrm{~mm}$ olarak kabul edilen zemin nem rezervi Mayıs ayının başından Eylül ayı başına kadar harcanmıştır. Sıcaklıkların artmasıyla Haziran ayı başından Ekim ayı sonlarına kadar gerçekleşen su noksanı ise $581.54 \mathrm{~mm}$ 'dir. Tüm bu verilere göre; $499 \mathrm{~mm}$ olan yıllık yağışın 472.44 mm'lik kısmı buharlaşarak atmosfere dönmektedir.

\section{Yeraltısuyu dinamiği}

Çivril Ovası'nda Devlet Su İşleri tarafından açılmış çok sayıda sondaj kuyusu bulunmaktadır. Kuyuların derinlikleri 84-196m arasında değişmektedir. Ovada sondaj kuyularıyla alüvyon, konglomera ve kireçtaşından yeraltısuyu üretimi yapılmaktadır. Çivril-Baklan Ovası'nda yeraltısuyu seviyesini belirlemek amacıylasondaj kuyularında Eylül 2015 döneminde statik seviye ölçümleri yapılmıştır. Baklan ovasında ölçüm yapılabilecek sondaj kuyusu olmadığından seviye ölçümleri Çivril ovasında gerçekleştirilmiştir. Çivril Ovası için hazırlananyeraltısuyu seviye haritasında yeraltısuyu akım yönününovanın kuzeydoğusunda Kufi çayına doğru olduğu tespit edilmiştir. Akım yönü, güneyde ve batıda ise 
ovanın ortasına doğrudur (Şekil 10). Ovanın bu kesimleri için akiferin yapısını görmek amacıyla DSi tarafından önceki yıllarda araştırma amaçlı olarak açılmış sondaj logları kullanılarak panel diyagram hazırlanmıştır (Şekil 11). Diyagramda ova tabanında çok kalın (yaklaşık $50 \mathrm{~m}$ ) bir marn tabakasının olduğu görülmek- tedir. Akifer ortam içerisinde çakıllı ve kumlu seviyelerden yeraltısuyu alınmaktadır. Yeraltısuyu akım yönünün ovanın orta kesimlerine doğru olması geçirimsiz temelin çukurlaşması ve aşırı su çekimi ile ilişkili olabileceği düşünülmektedir.

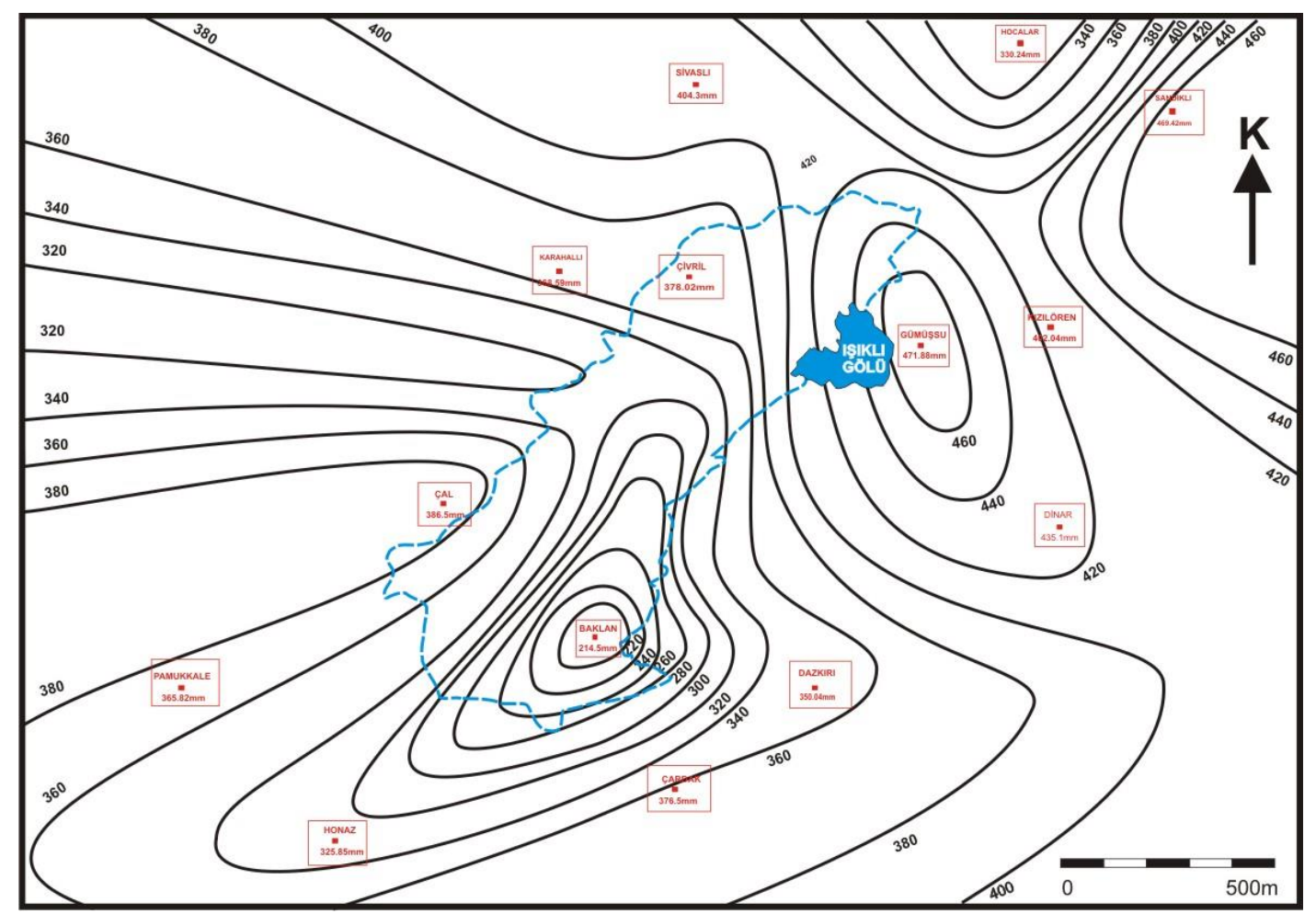

Şekil 8. İnceleme alanı izohiyet haritası

Tablo 2. Çivril-Baklan havzasına ait deneştirmeli su bütçesi

\begin{tabular}{|c|c|c|c|c|c|c|c|c|c|c|c|c|c|}
\hline & $\begin{array}{c}\text { OCA } \\
\mathrm{K}\end{array}$ & $\begin{array}{l}\text { ŞU- } \\
\text { BAT }\end{array}$ & $\begin{array}{c}\text { MAR } \\
T\end{array}$ & $\begin{array}{l}\mathrm{Ni}- \\
\text { SAN }\end{array}$ & $\begin{array}{l}\text { MA- } \\
\text { YIS }\end{array}$ & $\begin{array}{l}\text { HAZi- } \\
\text { RAN }\end{array}$ & $\begin{array}{l}\text { TEM- } \\
\text { MUZ }\end{array}$ & $\begin{array}{l}\text { AĞUS- } \\
\text { TOS }\end{array}$ & $\begin{array}{l}\text { EY- } \\
\text { LÜL }\end{array}$ & $\begin{array}{c}\text { EKI } \\
\text { M }\end{array}$ & $\begin{array}{l}\text { KA- } \\
\text { SIM }\end{array}$ & $\begin{array}{l}\text { ARA- } \\
\text { LIK }\end{array}$ & $\begin{array}{l}\text { TOP- } \\
\text { LAM }\end{array}$ \\
\hline Aylık Endeks (i) & 1,28 & 1,49 & 2,19 & 4,10 & $\begin{array}{c}6,15 \\
106,5\end{array}$ & 8,91 & 11,57 & 12,06 & 7,73 & $\begin{array}{l}4,96 \\
64,5\end{array}$ & 2,08 & 1,74 & 64,27 \\
\hline $\begin{array}{l}\text { Yağış (mm) } \\
\text { Zemin Rezervi }\end{array}$ & 38,4 & 23,9 & 58,8 & 72,4 & 75 & 31,1 & 48,3 & 11,9 & 10,4 & 48,1 & 32 & 48,7 & 499,00 \\
\hline$(\mathrm{mm})$ & 100 & 100 & 100 & 100 & $\begin{array}{l}68,45 \\
106,5\end{array}$ & 0 & 0 & 0 & 0 & 0 & 11,71 & 44,16 & 524,32 \\
\hline$(\mathrm{mm})$ & - & - & - & - & $-31,55$ & $-68,45$ & 0 & 0 & 0 & $\begin{array}{c}0 \\
16,4\end{array}$ & 11,71 & 32,44 & - \\
\hline Su Noksanı (mm) & - & - & - & - & - & 66,47 & 179,35 & 211,83 & 107,41 & 7 & - & - & 581,54 \\
\hline $\begin{array}{l}\text { Su Fazlası }(\mathrm{mm}) \\
\text { Enlem Düz. Katsa- }\end{array}$ & 26,72 & 10,19 & 32,26 & 13,24 & - & - & - & - & - & - & - & - & 82,41 \\
\hline yısı & 0,85 & 0,84 & 1,03 & 1,10 & 1,23 & 1,24 & 1,25 & 1,17 & 1,04 & 0,96 & 0,84 & 0,83 & 12,38 \\
\hline
\end{tabular}




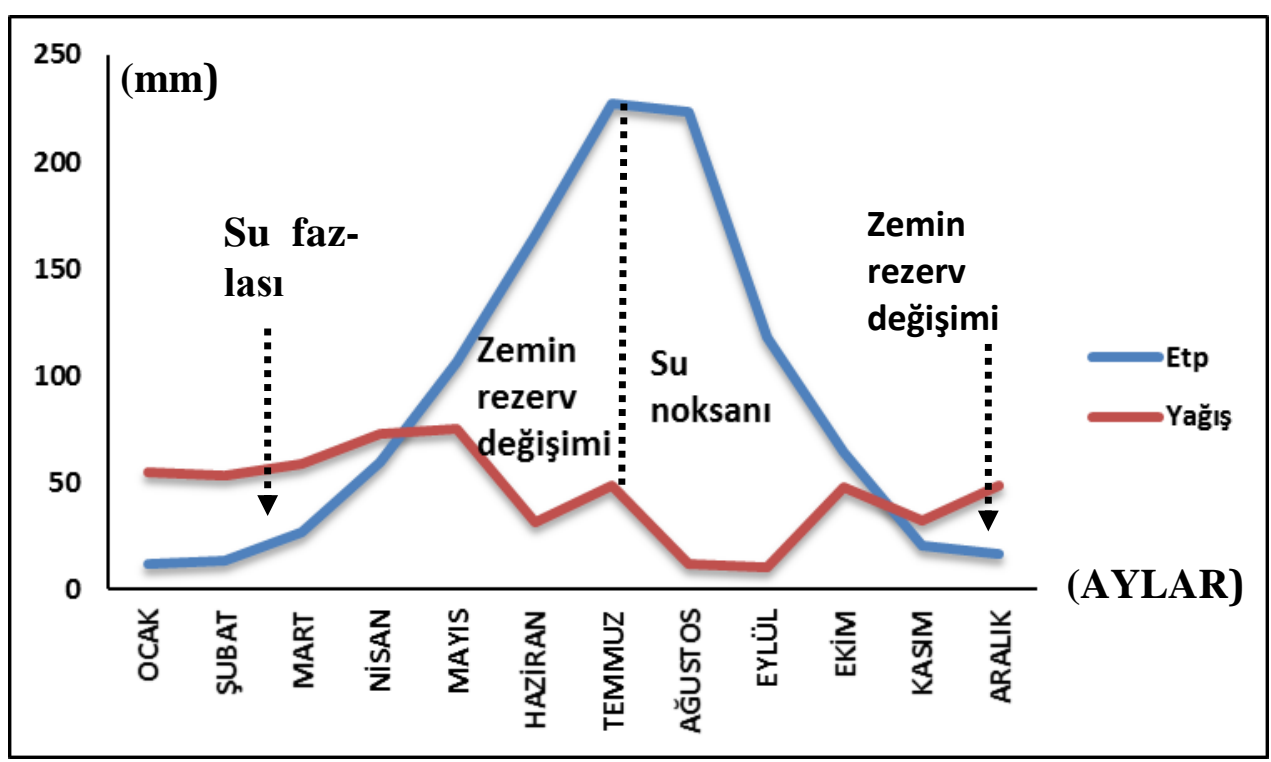

Şekil 9. Aylık Etp-yağış (mm) değişim grafiği

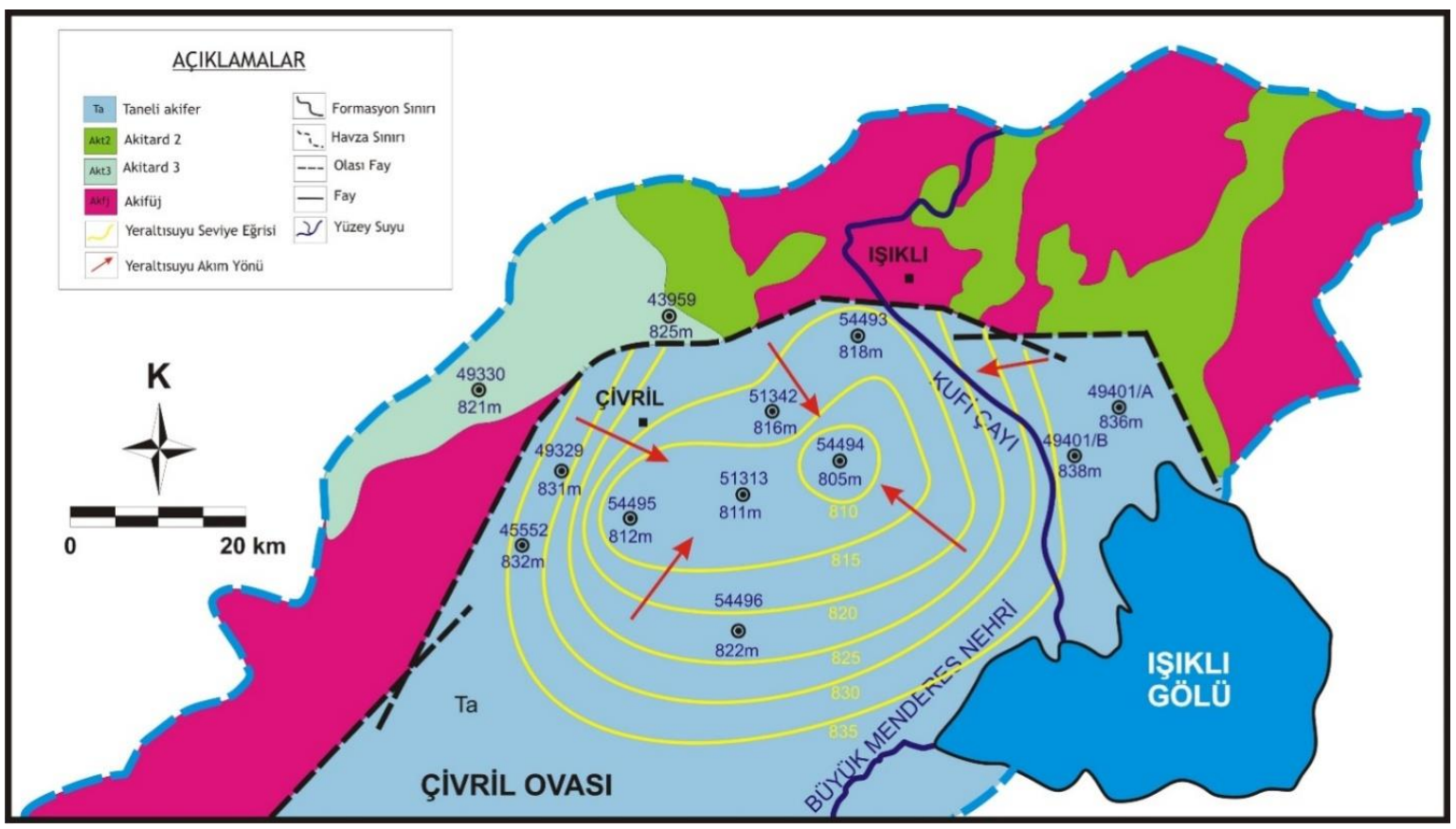

Şekil 10. İnceleme alanı yeraltısuyu seviye haritası 


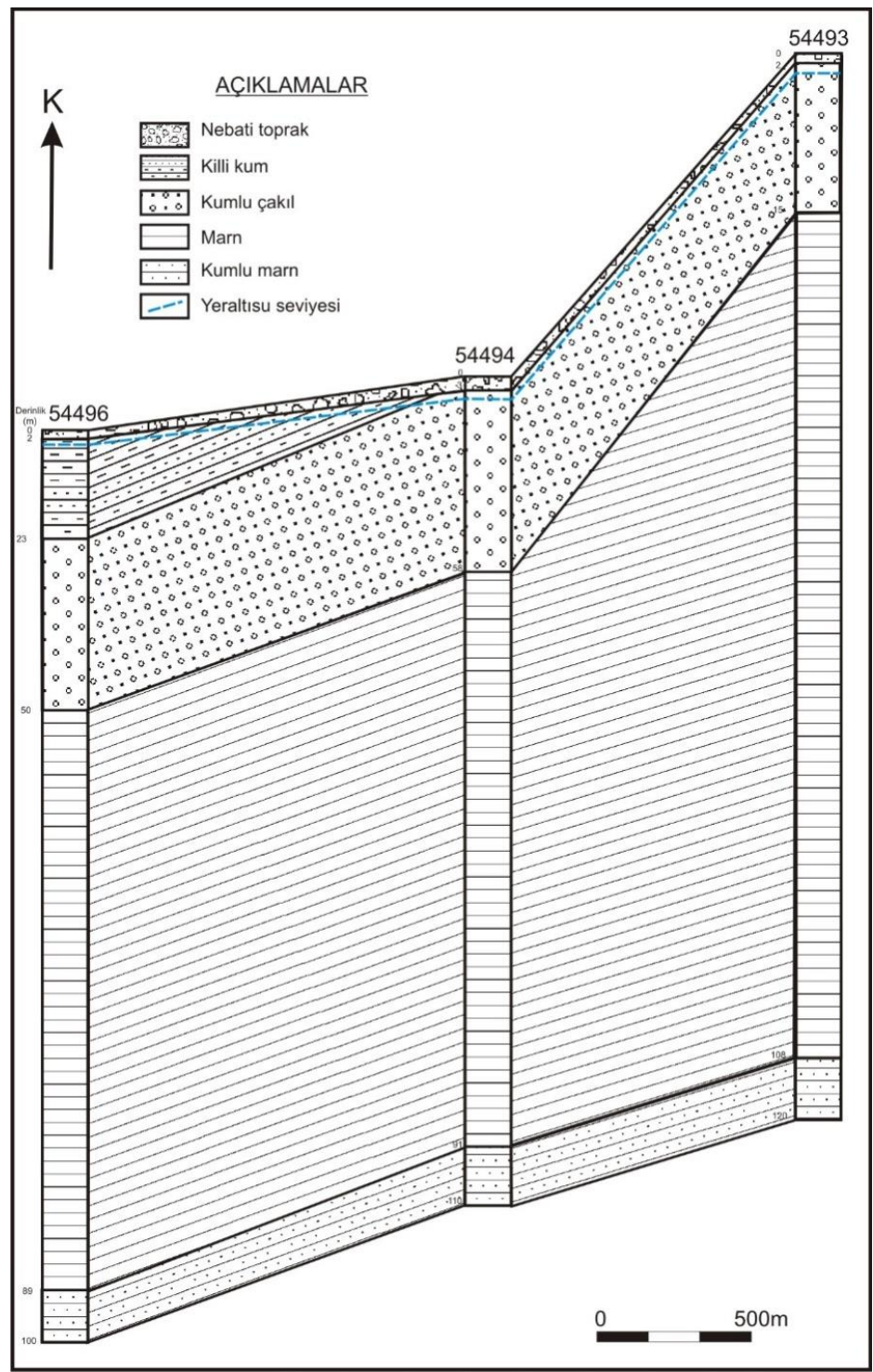

Şekil 11. Panel diyagram

\section{Klimatoloji}

\section{İklim sınıflandırması}

İklim, geniş bölgelerde çok uzun zaman içinde gerçekIeşen ortalama hava koşullarıdır. İklim tipleri sayısız denecek kadar çoktur. Ancak her bilim dalında olduğu gibi, klimatolojide de dağınık olan tiplerin, az çok ortak yanlı olanlarını bir araya getirerek büyük iklim kuşakları ortaya çıkartılmıştır. Araştırmacıların iklim analizinde dikkate aldığı kriterler farklıdır. Bunlardan bazıları; yağış - sıcaklık oranı, yağış - buharlaşma oranı, yağış rejimi ve bitki örtüsüdür. Gerek iklim sınıflandırması ve gerekse iklim analizi çalışmalarında olabildiğince uzun yıllık ortalamalar ve güvenilir-homojen verinin kullanıması gerekir (Dönmez, 1984). Bu çalışmada De Martonne, Erinç ve Aydeniz gibi bilim adamlarının yaptığı iklim sınıflandırmaları değerlendirilmiş ve bölgenin iklim tipi belirlenmiştir.

\section{De Martonne iklim sınıflandırması}

De Martonne'un iklim sınıflandırmasında aylık ve yıllık sıcaklık ile yağış verileri dikkate alınmaktadır. Yılık ortalama yağış ve sıcaklığın yanında, Temmuz ve Ocak ayı sıcaklık ve yağış ortalamaları arasındaki ilişki hesaplamada göz önünde tutulmaktadır. Yıllık yağış miktarı yağışlı ve kurak iklimleri ayırmaya imkân verir. Kurak devrelerin tespitinde aylık yağışların yanında buharlaşma da önemli bir parametredir (DMI, 1972).

De Martonne'un 1942'de geliştirdiği yıllık kuraklıkindisi (la)(1) no'luformül (KŞM, 2014) ile hesaplanır ve Tablo 
3'deki indislere göre değerlendirilerek iklim tipi belirlenir.

$$
l a=(P /(T+10)+(12 * p) /(t+10))) / 2
$$

Burada;

$$
\begin{array}{ll}
10 & =\text { Sıcaklığın } 0^{\circ} \mathrm{C} \text { 'nin altında olduğu yerlerde t'yi } \\
& \text { pozitif yapmaya yarayan sabit sayı } \\
\mathrm{P} & =\text { Uzun yıllar toplam yağış }(\mathrm{mm}) \\
\mathrm{T} & =\text { Uzun yıllar ortalama hava sıcaklığı }\left({ }^{\circ} \mathrm{C}\right) \\
\mathrm{p} & =\text { En kurak ayın yağışı }(\mathrm{mm}) \\
\mathrm{t} & =\text { En kurak ayın ortalama sıcaklığı }\left({ }^{\circ} \mathrm{C}\right)
\end{array}
$$

Tablo 3. De Martonne indisleri ve iklim tipleri (KŞM, 2014)

\begin{tabular}{ll}
\hline İklim Tipi & Kuraklık İndeksi \\
\hline Çöl & $0-5$ \\
Step (Yarı Kurak) & $5-10$
\end{tabular}

\begin{tabular}{ll} 
Step-Nemli arası & $10-20$ \\
Yarı Nemli & $20-28$ \\
Nemli & $28-35$ \\
Çok Nemli & $35-55$ \\
Islak & $>55$ \\
Kutupsal & $<0\left(\mathrm{~T}<-5^{\circ} \mathrm{C}\right)$ \\
\hline
\end{tabular}

Bu formülü Çivril bölgesi için uygularsak kuraklık indisi; $\mathrm{la}=\left(409 /(12.9+10)+\left(12^{*} 3.7 /(23.4+10)\right)\right) / 2=16.5 \mathrm{bu}-$ lunur.

Bu duruma göre Çivril ilçesi ve civarı De Martonne metoduna göre "step-nemli" iklim tipindedir (Tablo 3). Baklan bölgesinde ise yeterli veri olmadığı için iklim tipi hesaplanamamıştır. Ayrıca Türkiye De Martonne metodu ile hazırlanmış iklim sınıflandırması haritasına göre de bu bölgenin "step-yarı nemli" iklim bölgesinde yeraldığı görülmektedir (Şekil 12).

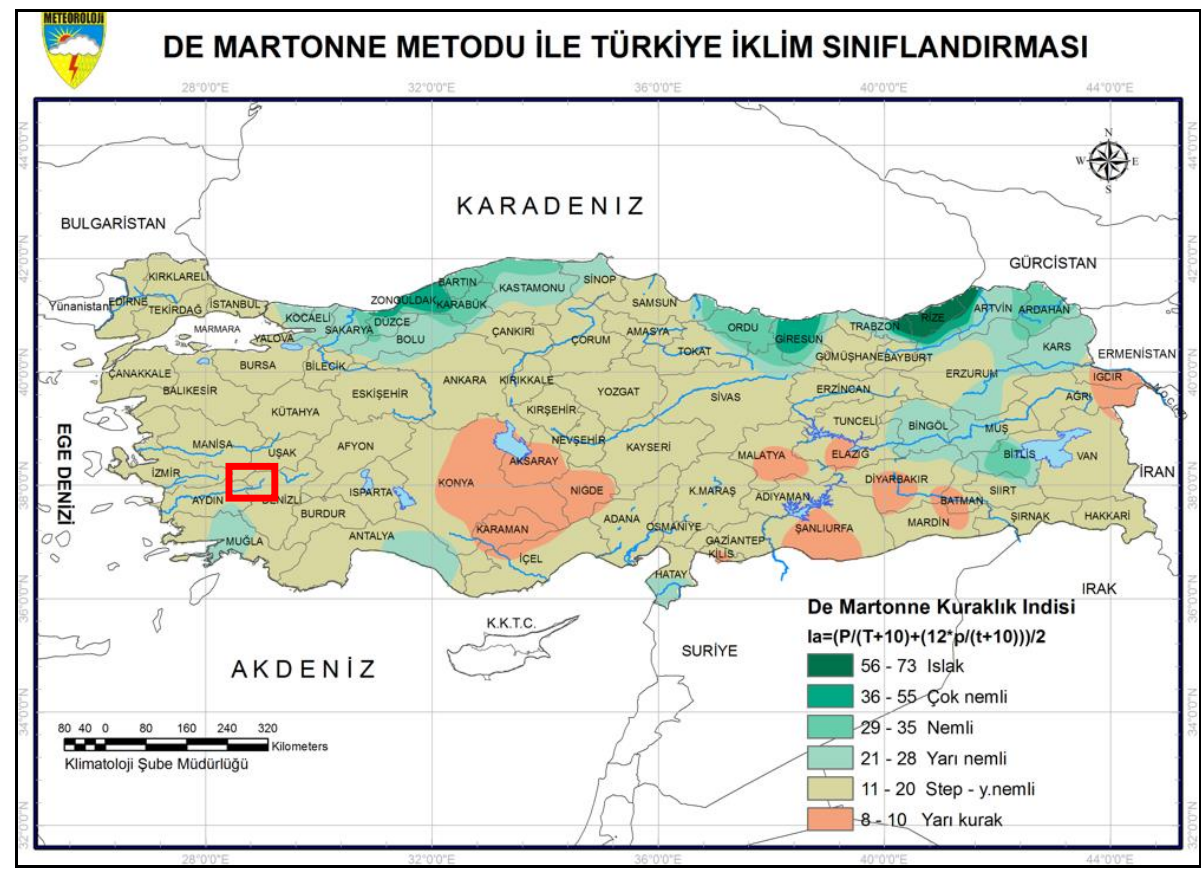

Şekil 12. De Martonne metodu ile Türkiye iklim sınıflandırması (KŞM, 2014)

\section{Erinç iklim sınıflandırması}

Yağış miktarlarının doğrudan ortalama sıcaklıklara oranlanması ile elde edilen indis, karasal bölgelerde gerçekte olduğundan daha nemli bir durumun ortaya çıkmasına sebep olmaktadır. Bu nedenle Erinç, indisin hesaplanmasında ortalama sıcaklık yerine ortalama maksimum sıcaklığı almıştır. Ancak bu değerlendirmede ortalama maksimum sıcaklığın $0^{\circ} \mathrm{C}$ 'nin altına düştüğü aylar, evapotranspirasyonun olmadığı varsayılarak dikkate alınmaz (Erinç, 1984). Erinç iklim indisi (2) no’lu formül ile hesaplanmaktadır.
Yağış Etkinlik İndisi $(\mathrm{Im})=\mathrm{P} / \mathrm{T}_{\mathrm{om}}$

Burada;

$\begin{array}{ll}\mathrm{P} & =\text { Yıllık toplam yağış }(\mathrm{mm}) \\ \mathrm{T}_{\mathrm{om}} & =\text { Yıllık ortalama maksimum sıcaklık }\end{array}$

Erinç, elde edilecek indis değerlerine göre 6 ayrı iklim sınıfı tanımlamıştır. 
Tablo 4. Erinç iklim indis değerleri ile bunlara bağlı bitki örtüsü ve iklim sınıfları (KŞM, 2014)

\begin{tabular}{|l|l|l|}
\hline $\begin{array}{l}\text { İklim Sı- } \\
\text { nıfı }\end{array}$ & $\begin{array}{l}\text { İndis Değeri } \\
(\mathbf{I m})\end{array}$ & Bitki Örtüsü \\
\hline $\begin{array}{l}\text { Tam Ku- } \\
\text { rak }\end{array}$ & $<8$ & Çöl \\
\hline Kurak & $8-15$ & Çöl-Step \\
\hline $\begin{array}{l}\text { Yarı Ku- } \\
\text { rak }\end{array}$ & $15-23$ & Step \\
\hline Yarı Nemli & $23-40$ & $\begin{array}{l}\text { Park görünümlü } \\
\text { kuru orman }\end{array}$ \\
\hline Nemli & $40-55$ & Nemli orman \\
\hline Çok Nemli & $>55$ & Çok nemli orman \\
\hline
\end{tabular}

Çivril bölgesi için Erinç kuraklık indisi; Im= 411/12=34 olarak hesaplanmıştır.

Çivril bölgesi Erinç iklim sınıflandırmasına göre "yarı nemli" iklim tipine ve "park görünümlü kuru orman" bitki örtüsüne sahiptir (Tablo 4). Baklan bölgesine ait yeterli veri olmadığından hesaplama yapılamamıştır. Erinç metoduna göreçizilen Türkiye iklim sınıflandırması haritasına göre ise Çivril-Baklan ovası "yarı nemli" iklim tipine sahiptir (Şekil 13).

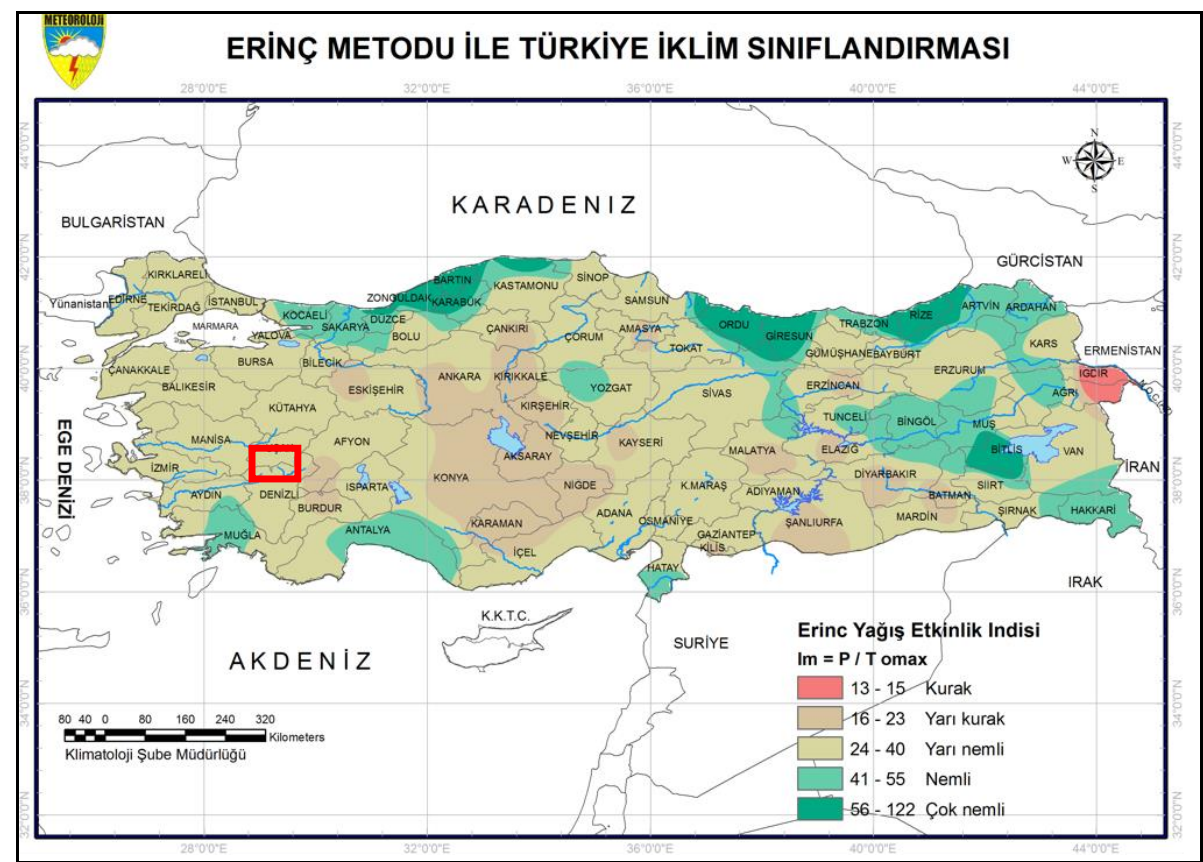

Şekil 13. Erinç metodu ile Türkiye iklim sınıflandırması (KŞM, 2014)

\section{Aydeniz iklim sınıflandırması}

AÜ Ziraat Fakültesi öğretim üyesi Prof. Dr. Akgün Aydeniz'in geliştirdiği formülde, yağış, sıcaklık, nispi nem ve güneşlenme süresi verileri kullanılmaktadır (DMi, 1988). Çivril ve Baklan bölgesinde nispi nem ve güneşlenme süresi verileri yeterli olmadığı için bölge Aydeniz metoduna göre değerlendirilememiştir. Ancak Aydeniz metodu ile hazırlanan Türkiye haritasına göre ise bölgenin "yarı kurak" iklim bölgesinde yeraldığı görülmektedir (Şekil 14).

Sonuç olarak çalışma alanında yapılan iklim sınıflandırmasının Türkiye haritasına göre değerlendirilmesi özet şeklinde Tablo 5'de sunulmuştur.
Tablo 5. Çivril-Baklan ovası iklim sınıflandırması

\begin{tabular}{|l|l|l|l|}
\hline Yer & $\begin{array}{l}\text { İklim sınıflan- } \\
\text { dırma metodu }\end{array}$ & $\begin{array}{l}\text { İklim } \\
\text { indis } \\
\text { aralığı }\end{array}$ & İklim tipi \\
\hline $\begin{array}{l}\text { Çivril- } \\
\text { Baklan } \\
\text { ovası }\end{array}$ & De Martonne & $11-20$ & $\begin{array}{l}\text { Step-Yarı } \\
\text { nemli arası }\end{array}$ \\
\hline $\begin{array}{l}\text { Çivril- } \\
\text { Baklan } \\
\text { ovası }\end{array}$ & Erinç & $24-40$ & Yarı nemli \\
\hline $\begin{array}{l}\text { Çivril- } \\
\text { Baklan } \\
\text { ovası }\end{array}$ & Aydeniz & $\begin{array}{l}0,76- \\
1,00\end{array}$ & Yarı kurak \\
\hline
\end{tabular}




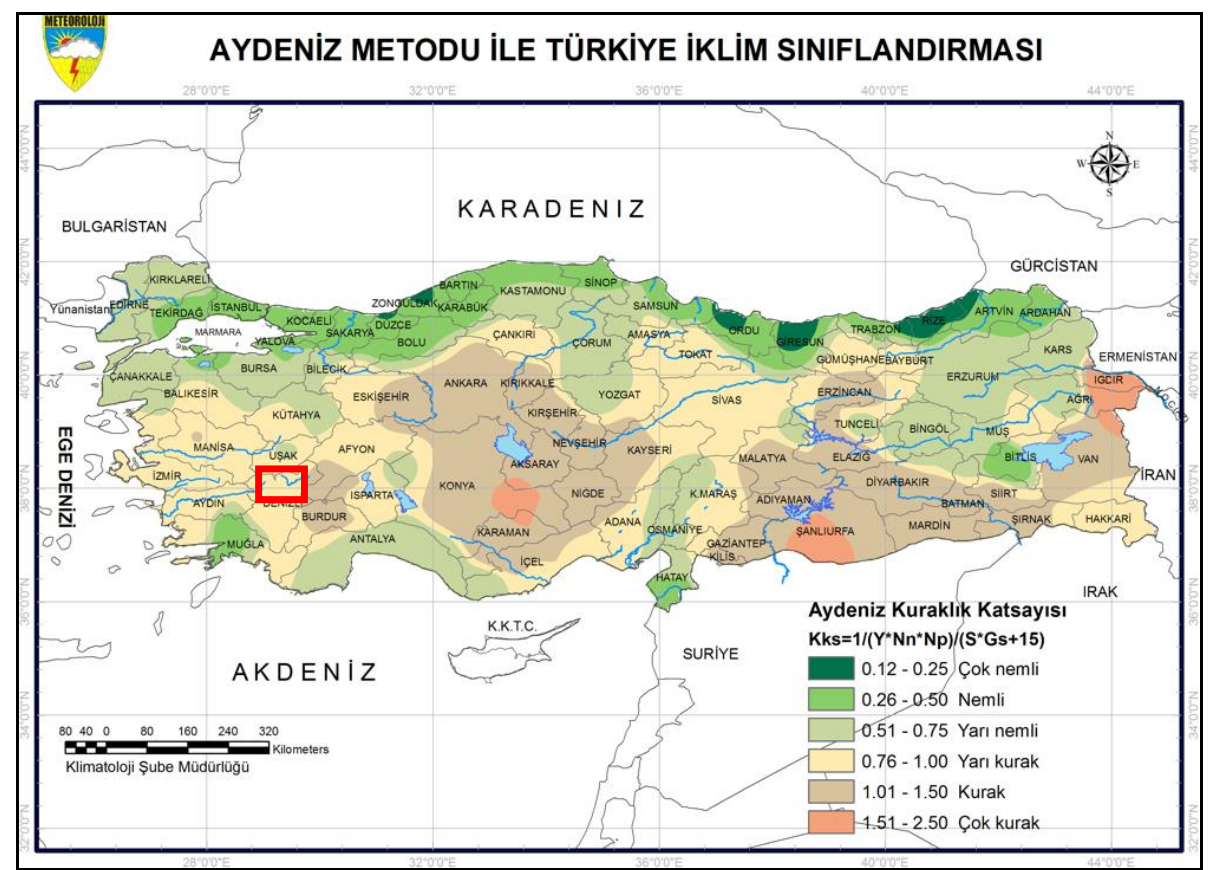

Şekil 14. Aydeniz metodu ile Türkiye iklim sınıflandırması (KŞM, 2014)

\section{Yeraltısuyu seviyeleri-yağış-sıcaklık ilişkisi}

Yeraltısuyu seviye değişimini denetleyen en önemli parametreler olan yağış ve sıcaklık ölçümleri su seviye ölçümleri ile ilişkilendirilmiştir. Bu değerlendirmeler için Çivril DMi'nda ölçülen yağış ve sıcaklık değerleri ile DSi 21. bölge tarafından düzenli olarak yapılan yeraltısuyu seviye verileri kullanılmıştır. Çivril'de kurulan ilk meteoroloji istasyonunda 1968-1992 yılları arası, ikinci istasyonda ise 2007-2015 yılları arasında yağış ve sıcaklık ölçümleri yapılmıştır. İlk istasyonda 1968-1992 yılları için ortalama yağış miktarı $447.23 \mathrm{~mm}$ (Şekil 15), ikinci istasyonda 2007-2015 yılları arasında ölçülen ortalama yağış miktarı 460.86 mm'dir (Şekil 16). Bu araştırmada Çivril DMi'larında ölçülen yıllık yağışların zamansal değişimlerinin belirlenmesi amacıyla ortalama yıllık yağıştan eklenik sapma analizleri gerçekleştirilmiştir (Şekil 15, 16). Çivril'de kurulan DMi verilerine göre1969-1971 yılları arası yağışı dönem, 1971-1977 yılları arası kurak dönem, 1977-1984 yılları arası yağışı dönem ve 1984-1992 yılları arası yine kurak dönem gözlenirken 2008-2012 yılları arası yağışlı dönem,
2012-2015 yılları arası kararlı dönem gözlenmiştir (Şekil 17, 18). Bu istasyonda ölçülen yağış-sıcaklık ilişkilerine bakıldığında ortalama sıcaklık değerlerinin yağışın arttığı yılllarda genel olarak düştüğü görülmektedir (Şekil 19, 20). DSi 21. Bölge Müdürlüğü tarafından Çivril Ovasında bulunan 13 adet kuyuda 2000-2014 yılları arasında düzenli yeraltısuyu seviye ölçümleri yapılmaktadır. Yağışlı ve kurak dönem dikkate alınarak yıllara göre seviye değişim grafiği hazırlanmıştır (Şekil 21, 22). Grafikte yağışı dönemi temsil eden Mayıs ayı statik seviye değerlerinin kurak dönemi temsil eden kasım ayı ölçümlerine göre yüksek olduğu görülmektedir. Bu durum uzun yıllar bazında yağıştan yeraltısuyunun beslendiğini ve su seviyesinin arttığını göstermektedir. Kurak dönemde hem yağıştan beslenim miktarının azalması hem de kuyulardan yeraltısuyu çekilmesi statik seviyeyi düşürmektedir. Bölgede genel olarak bütün kuyularda yeraltısuyu seviyesinin 5 m'den daha aşağı olması nedeniyle sıcaklık değişimlerinden fazla etkilenmemektedir. Bölgede yeraltısuyu seviye değişimini etkileyen en önemli iklimsel parametre yağış miktarındaki artış ve azalışlardır. 


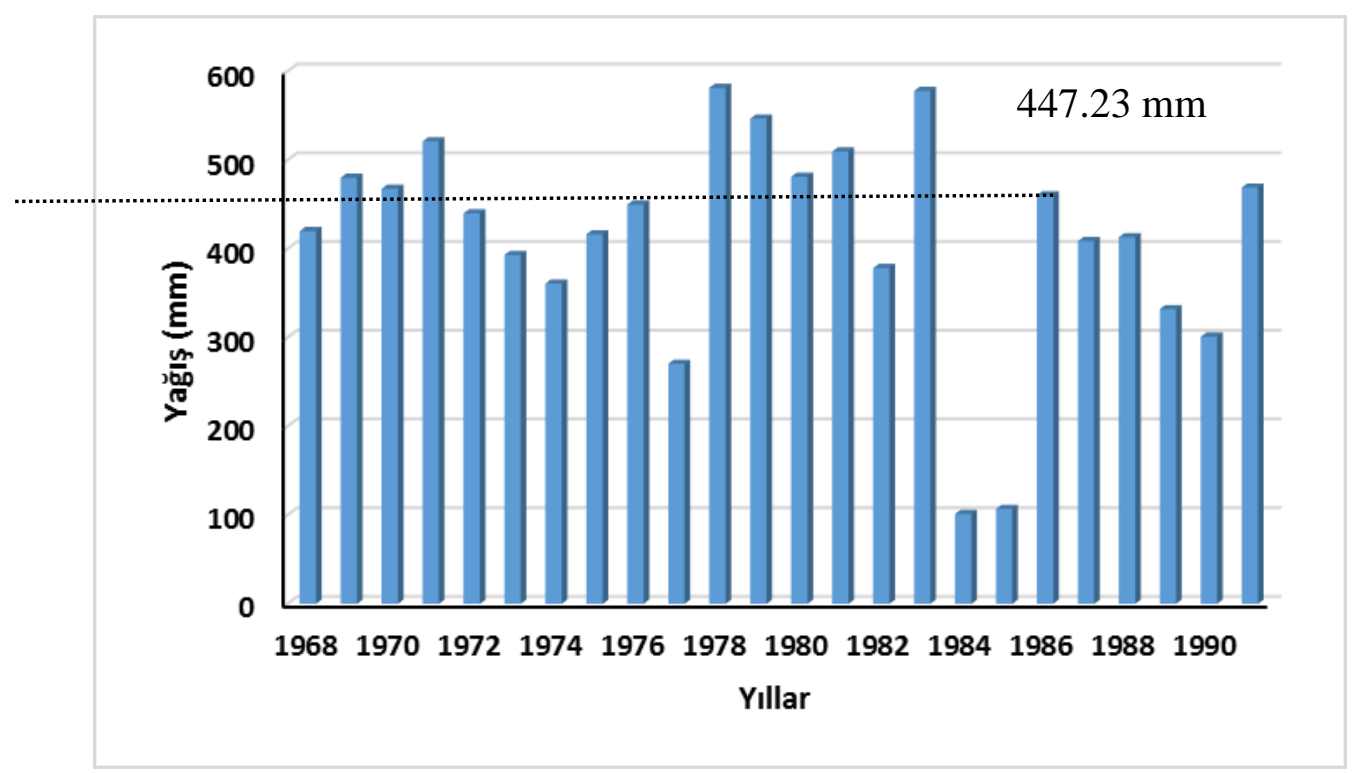

Şekil 15. Çivril yıllık yağış dağılım grafiği (1968-1990)

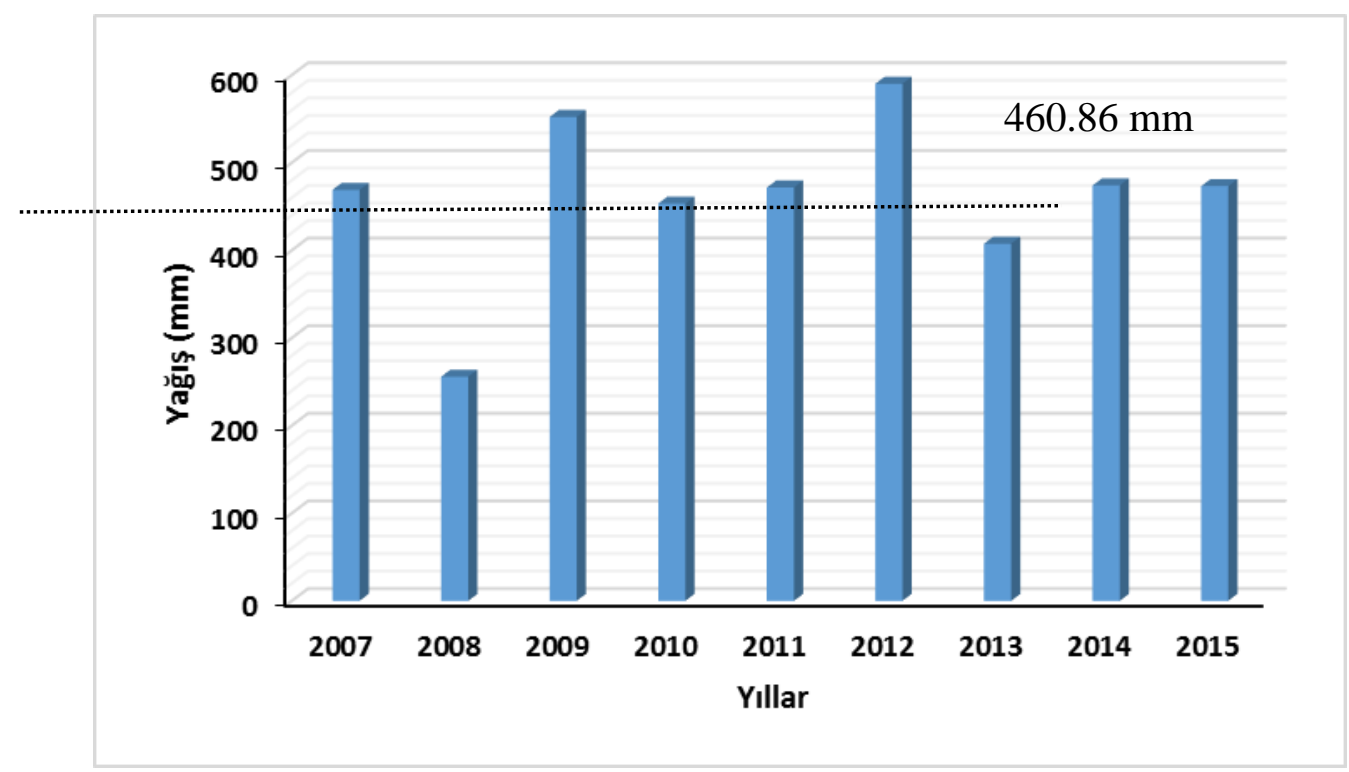

Şekil 16. Çivril yıllık yağış dağılım grafiği (2007-2015) 


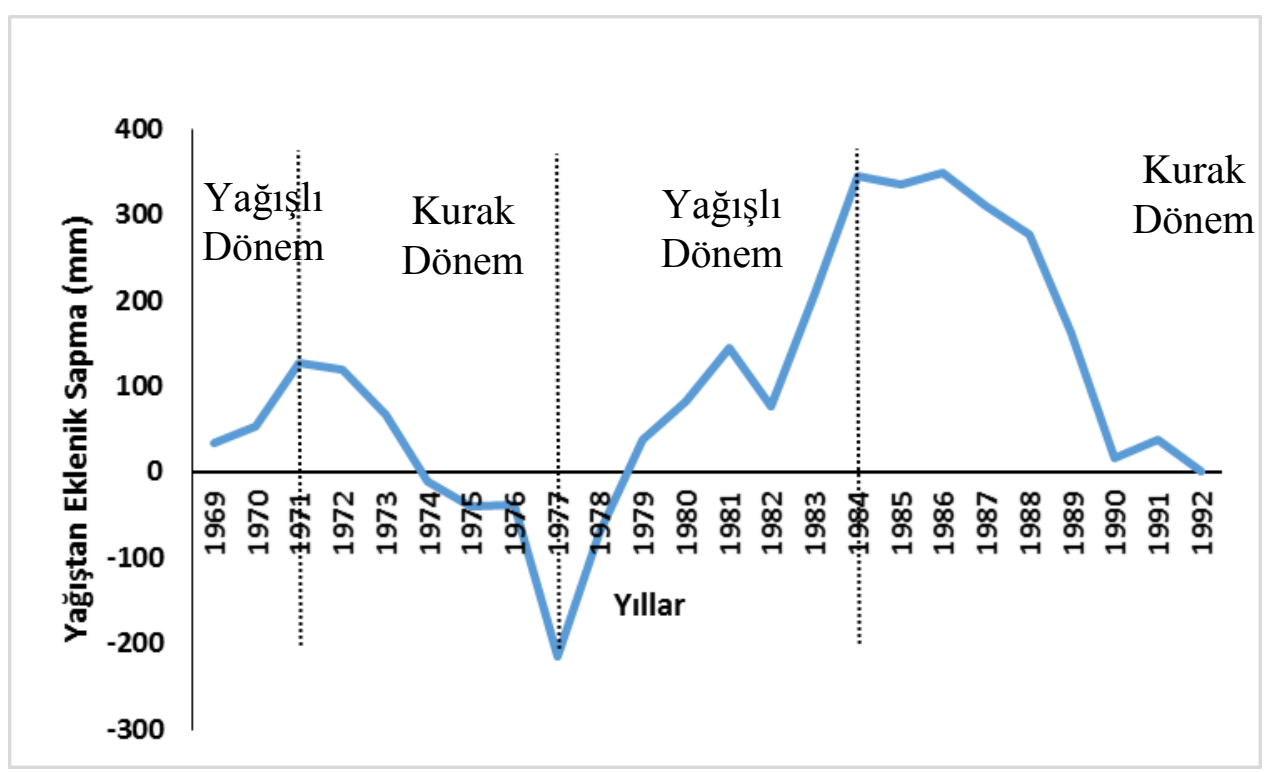

Şekil 17. Çivril 5986 nolu DMi'na ait eklenik sapma grafiği

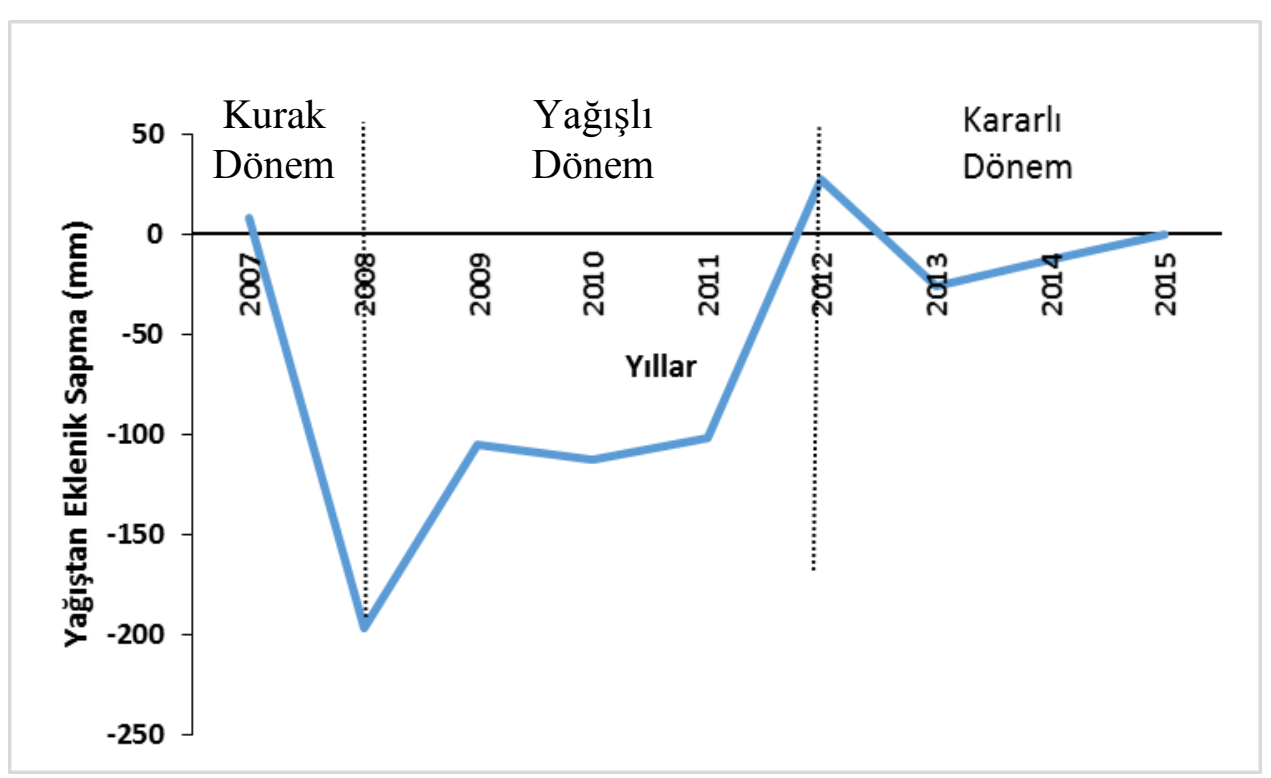

Şekil 18. Çivril 17825 nolu DMi'na ait eklenik sapma grafiği 


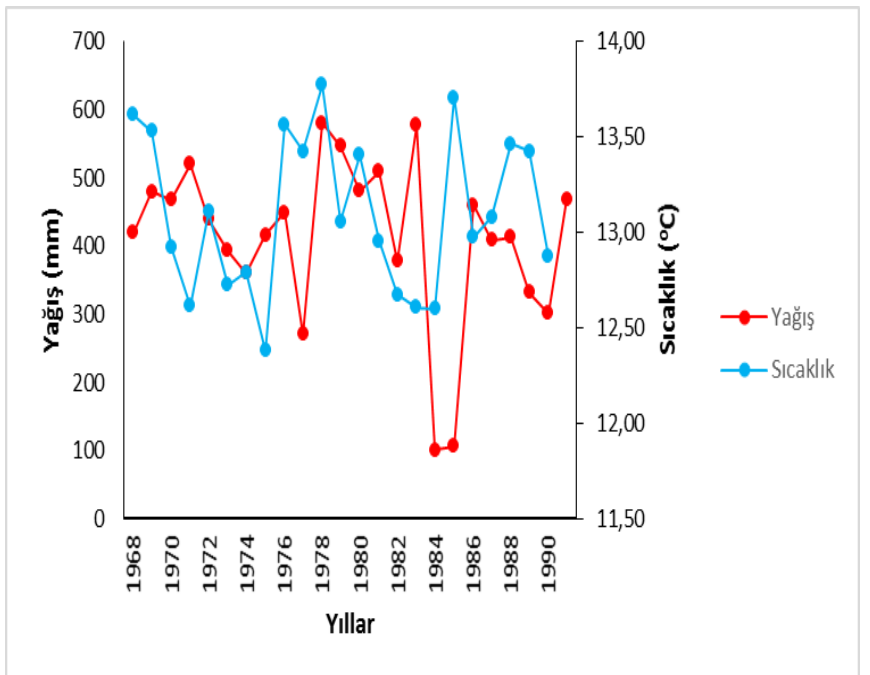

Şekil 19. Çivril sıcaklık-yağış değişim grafiği (19681990)

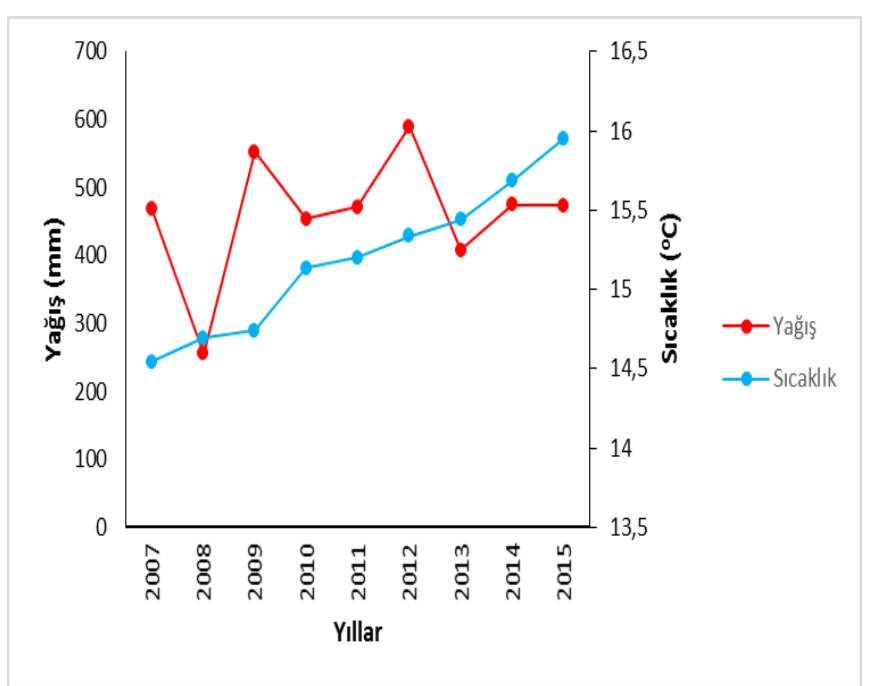

Şekil 20. Çivril sıcaklık-yağış değişim grafiği (20072015)

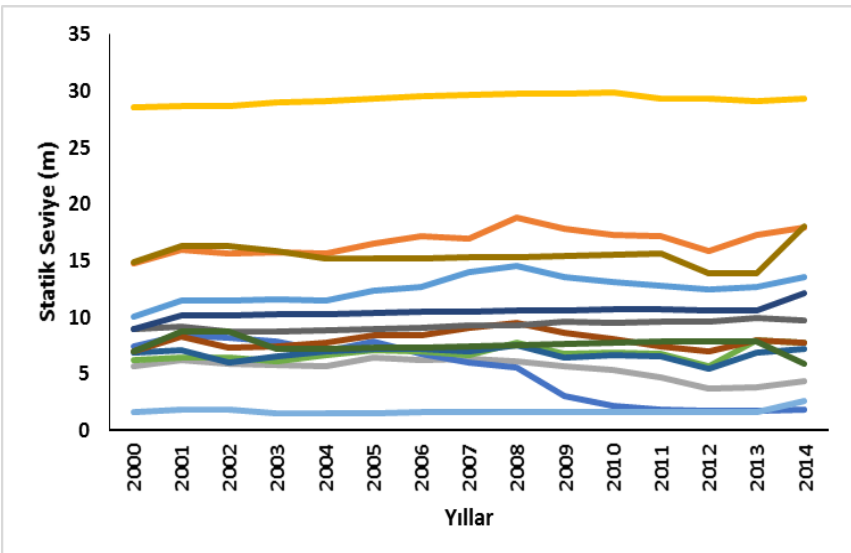

Şekil 21. Sondaj kuyularındaki seviye değişim grafiği (Kasım)

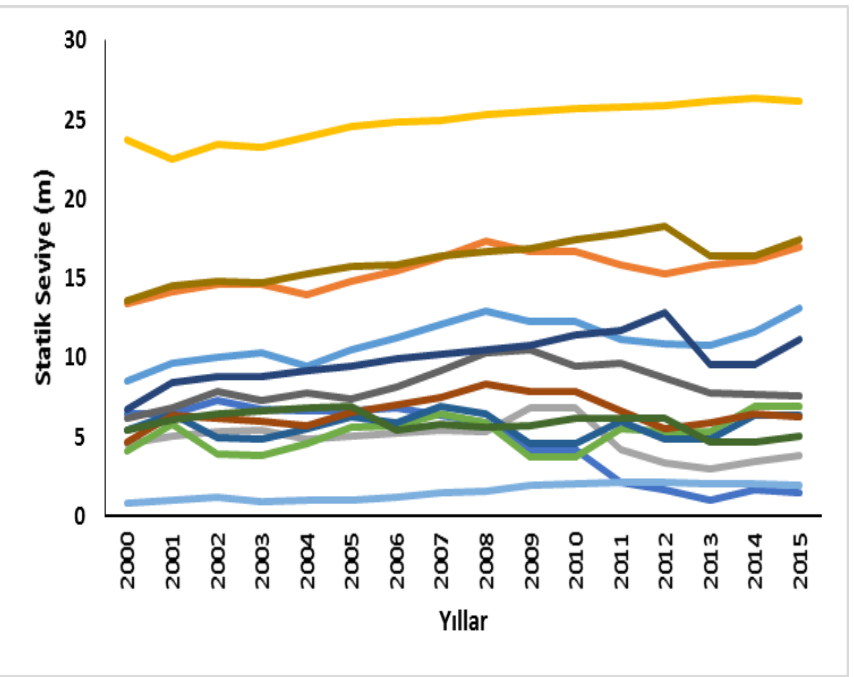

Şekil 22. Sondaj kuyularındaki seviye değişim grafiği (Mayıs)

\section{SONUÇLAR}

Çalışma alanı olarak seçilen Çivril-Baklan Ovası geniş yayılımlı bir alana sahip olması nedeniyle yeraltı potansiyeli açısından zengin bir havza niteliğindedir. Havzanın yıllık ortalama yağış miktarı 409.56 mm'dir. Havzada geçmiş yıllara göre güncel sıcaklık miktarları değerlendirildiğinde bölgede sıcaklığın giderek arttığı görülmektedir. Ova için hesaplanan gerçek buharlaşma miktarı da $472.44 \mathrm{~mm}$ olarak belirlenmiştir. Yağış miktarının buharlaşma miktarına göre düşük olması havzada kuraklığa doğru bir eğilim olduğunun işaretidir. Kuraklık takibi için kuraklık indislerinin hesaplanması önemlidir. Çivril-Baklan havzası De Martonne metoduna göre "step-yarı nemli arası", Erinç metoduna göre "yarı nemli" ve Aydeniz iklim sınıflandırma metoduna göre de "yarı kurak" iklim tipine sahiptir. Yeraltısuyu seviye değişimini denetleyen en önemli parametreler olan yağış ve sıcaklık ölçümleri DSi tarafından yapılan uzun dönem yeraltısuyu seviye ölçümleri ile ilişkilendirilmiştir. Bu değerlendirmelere göre, yağışlı dönemi temsil eden Mayıs ayında statik seviye değerlerinin kurak dönemi temsil eden kasım ayı ölçümlerine göre yüksek olduğu görülmektedir. Bu durum uzun yıllar bazında yağıştan yeraltısuyunun beslendiğini ve su seviyesinin arttığını göstermektedir. Kurak dönemde hem yağıştan beslenim miktarının azalması hem de kuyulardan yeraltısuyu çekimi ile statik seviye değerini düşürmektedir. Bölgede genel olarak bütün kuyularda yeraltısuyu seviyesinin 5 m'den daha aşağı olması nedeniyle sıcaklık değişimlerinden fazla etkilenmemektedir. Bölgede yeraltısuyu seviye değişimini etkileyen en önemli iklimsel parametre yağış miktarındaki değişikliklerdir. 


\section{TEŞEKKÜR}

$\mathrm{Bu}$ çalışmanın yapılmasını destekleyen TÜBITAK 2209/A Üniversite Öğrencileri Yurtiçi Araştırma Projeleri Destek Programı'na teşekkürlerimizi sunarız.

\section{KAYNAKLAR}

Boyraz, S., Kazancı, N., İsmael, M.T., Öncel, S., İleri, Ö., Makaroğlu, Ö. (2011). Sediment Properties and Geological Evolution of the Recent Lake Işıklı (Denizli, SW Turkey). 18th International Petroleum and Natural Gas Congress and Exhibition of Turkey. 2011.

DMi (1972). Türkiye Iklim Tasnifi (De Martonne Metoduna Göre). Ankara

DMi (1988). Aydeniz Metodu ile Türkiye'nin Kuraklık Değerlendirmesi, Ankara

De Martonne, E. (1942). Nouvelle carte mondiale de l'indice d'aridité. Annales de Géographie 51:242-250.
Dönmez, Y. (1984). Umumi Klimatoloji ve İklim Çalışmaları I.T.Ü. Yayın No: 2506, Coğrafya Enstitüsü Yayını. 102.

Erinç, S. (1984). Klimatoloji ve Metotları, I.T.Ü. Deniz Bilimleri ve Coğrafya Enstitüsü, İstanbul

Konak, N., Akdeniz, N., Çakır. H. (1986). Çal-Çivril Karahallı Dolayının Jeolojisi. MTA Rapor No: 8945

KŞM (2014). Meteoroloji Genel Müdürlüğü, Klimatoloji Şube Müdürlüğü Kalaba, Ankara, Türkiye.

MGM (2015). TC Orman ve Su İşleri Bakanlığı Meteoroloji Genel Müdürlüğü veri bankası http://www.mgm.gov.tr/veridegerlendirme/il-ve-ilceleristatistik.aspx?m=DENIZLI, 31.06.2015

Özsoy, İ. (2011). Denizli ili 2011 yılı çevre durum raporu, TC Denizli Valiliği İl Çevre ve Şehircilik Müdürlüğü

Sözbilir, H. (1997). Sratigraphy and Sedimentology of The Tertiary Sequences in The Northeastern Denizli Province (Southwest Turkey), Doktora Tezi, Dokuz Eylül Üniversitesi, Fen Bilimleri Enstitüsü, s. 195.

Thornthwaite, C.W., Mather, J.R. (1957). Instructions and tables for computing potential evapotranspiration and the water balance; Publ. Climatol. 10 185-311. 